\title{
A NEW GENUS AND FOUR NEW SPECIES OF QUILL MITES (ACARI: Prostigmata: SYRINGophILIDAE) FROM PHASIANID BIRDS (GALLIFORMES: PhASIANIDAE)
}

\author{
SKORACKI M.* \& SIKORA B.*
}

\begin{abstract}
Summary:
A new genus and four new species of the quill mites are described. Galliphilopsis gen. n. (G. francolinus sp. n., type species) differs from the closely related Dissonus Skoracki, 1999 by loss of leg setae $d G l l$, the slightly divergent tips of epimeres I and the stylophore constricted posteriorly. Three new species of the genus Galliphilopsis gen. n. and one new species of the genus Mironovia Chirov and Kravtsova, 1995 are described from galliform birds (Phasianidae) collected at the Museum of Natural History, Wroclaw University (Poland): G. lophurus sp. n. from Lophura leucomelanos, G. bochkovi sp. n. from Tragopan sp. and Alectoris barbara, G. francolinus sp. n. from Francolinus

levalliantoides, and Mironovia rouloul sp. n. from Rollulus rouloul.
\end{abstract}

KEY WORDS : Syringophilidae, quill mites, taxonomy, Galliformes, ectoparasites.
Résumé : UN NOUVEAU GENRE ET QUATRE ESPĖCES NOUVELLES D'aCariens Plumicoles (ACari : Prostigmata : Syringophilidae) D'OIseaux Galliformes (Galliformes : Phasianidae)

Un nouveau genre et quatre nouvelles espèces d'acariens plumicoles sont décrits. Galliphilopsis gen. n. (G. francolinus sp. n., espèce typel diffère de Dissonus Skoracki, 1999, genre étroitement apparenté par l'absence des setae des pattes dGII, l'apex des epimères I légèrement divergent et le stylophore rétréci postérieurement. Trois nouvelles espèces du genre Gaalliphilopsis et une nouvelle espèce du genre Mironovia Chirov and Kravtsova, 1995 sont décrites chez des oiseaux galliformes (Phasianidae) de la collection du Muséum d'Histoire Naturelle de l'Université de Wroclaw (Pologne) : G. lophurus sp. n. sur Lophura leucomelanos, $G$. bochkovi sp. n. sur Tragopan sp. et Alectoris barbara, G. francolinus sp. n. sur Francolinus levalliantoides, et Mironovia rouloul sp. n. sur Rollulus rouloul.

MOTS CLÉS : Syringophilidae, acarien plumicole, taxonomie, Galliformes, ectoparasites.

Coraciiformes, Columbiformes, and Psittaciformes. The fauna of Syringophilidae from galliform birds is still poorly known. Among 218 species of this order (Zoonomen Nomenclatural data 2002) only 13 are known as hosts for quill mites and we suggest that there are still many not recognized species associated with galliform birds.

In the present paper we give a description of three new species of the new genus Galliphilopsis and one new species of the genus Mironovia Chirov and Kravtsova, 1995. All these mites were collected from galliform birds (Phasianidae): G. lophurus sp. n. from Lophura leucomelanos, G. bochkovi sp. n. from Tragopan sp. and Alectoris barbara, G. francolinus sp. n. from Francolinus levalliantoides, and Mironovia rouloul sp. n. from Rollulus rouloul.

\section{MATERIAL AND METHODS} 2001). All these genera, except Picobia, inhabit exclusively the galliform hosts. The widely distributed genus Picobia parasitize birds of the order Galliformes as well as the five other orders: Passeriformes, Piciformes,

\footnotetext{
* Department of Animal Morphology, A. Mickiewicz University, 28 Czerwca 1956/198, 61-485 Poznan, Poland.

Correspondence: M. Skoracki. E-mail: skoracki@main.amu.edu.pl
}

0 yringophilid specimens were acquired from the bird collection kept at the Museum of Natural History, Wroclaw University (Poland) (NMW). Coverts and body feathers were examined. Mites were mounted in lactic acid (10\%) within three days. After then, mites were mounted on microslides in a polivinylo- 


\begin{tabular}{|c|c|c|}
\hline Quill mite species & Host species & Host family \\
\hline \multirow[t]{2}{*}{ Colinophilus wilsoni Kethley, 1973} & Colinus virginianus & Phasianidae \\
\hline & Callipepla squamata & Phasianidae \\
\hline \multirow{3}{*}{$\begin{array}{l}\text { Galliphilopsis francolinus sp. } \mathrm{n} \text {. } \\
\text { G. bochkovi sp. n. }\end{array}$} & Francolinus levalliantoides & Phasianidae \\
\hline & Tragopan sp. & Phasianidae \\
\hline & Alectoris barbara & Phasianidae \\
\hline G. lophurus sp. n. & Lophura leucomelanos & Phasianidae \\
\hline \multirow[t]{2}{*}{ Kalamotrypetes colinastes Casto, 1980} & Colinus virginianus & Phasianidae \\
\hline & Callipepla squamata & Phasianidae \\
\hline K. pavodaptes Casto, 1980 & Meleagris gallopavo & Meleagrididae \\
\hline Mironovia phasiani Chirov and Kravtsova, 1995 & Phasianus colchicus & Phasianidae \\
\hline M. coturnae Bochkov et al., 2004 & Coturnix coturnix & Phasianidae \\
\hline M. rouloul sp. n. & Rollulus rouloul & Phasianidae \\
\hline Picobia alectori Fain et al., 2000 & Alectoris sp. & Phasianidae \\
\hline P. polonica Skoracki et al., 2001 & Gallus gallus & Phasianidae \\
\hline \multirow[t]{3}{*}{ Syringophilus bipectinatus Heller, 1880} & Gallus gallus & Phasianidae \\
\hline & Alectoris rufa & Phasianidae \\
\hline & Ptilopachus petrosus & Phasianidae \\
\hline S. numidae Bochkov, 2000 & Numida meleagris & Numididae \\
\hline
\end{tabular}

Table I. - The quill mite species associated with galliform birds (Galliformes).

lactophenol medium and examined with the Nomarsky interference-contrast-phase with microscope Olympus $\mathrm{BH} 2$. The precise data on the localities for many investigated birds were unknown. The nomenclature of idiosomal setae follows Fain (1979) in the version adapted for the family Syringophilidae (Bochkov \& Mironov, 1998) and the chaetotaxy for the legs is that of Grandjean (1944). Bird taxonomy follows that of Howard and Moore (1991). All measurements in descriptions are given in micrometers $(\mu \mathrm{m})$. The setal measurements of the holotypes are incomplete, because some setae are broken. The holotypes and most of the paratypes are deposited at the Department of Animal Morphology, A. Mickiewicz University, Poznan, Poland (UAM). Some paratypes are deposited at the Zoological Institute of the Russian Academy of Sciences, St. Petersburg, Russia (ZIN) and at the Smithsonian National Museum of Natural History (SNM).

\section{RESULTS}

Family Syringophilidae Lavoipierre, 1953.

Subfamily Syringophilinae Lavoipierre, 1953.

\section{GENUS GALLIPHILOPSIS GEN. N.}

Type species Galliphilopsis francolinus sp. n. Host order: Galliformes.

- Description

Female. Small mites (total body length 400-550 $\mu \mathrm{m}$ ). Hypostomal apex rounded without protuberances. Lateral hypostomal teeth absent. Cheliceral digit edentate. Peritremes M-shaped, longitudinal branches short with two-three chambers. Stylophore constricted posteriorly. All idiosomal setae smooth. Propodosomal plate weakly sclerotized. Setal pattern of propodosomal region with five pairs of propodosomal setae present: $v e, s c i, h, s c e$ and $d 1$ (vi-absent), arranged 1-1-1-2 (Fig. 1). Hysterosomal plate variable, weakly sclerotized or absent. Genital and anal series with two pairs of setae, respectively. Paragenital series with three pairs of setae. Epimeres I slightly divergent anteriorly, not fused to epimeres II. Leg setae smooth (except $p$ ' and $p$ '-multiserrate), setae $d G I I$ and $d T I I I-I V$, absent. Antaxial and paraxial members of claw pair subequal.

Male unknown.

\section{- Differential diagnosis}

This new genus is closely related to the genus Dissomus Skoracki, 1999 associated with passeriform birds (Passeriformes) (Skoracki, 1999). In both genera setae $v i$, $d T I I I$ and $d T I V$ are absent, setae vs'II, $s c 1$ and $s c 2$ are present. There are two pairs of anal setae. Galliphilopsis gen. n. is distinguished from Dissonus by absence of setae $d G I I$, slightly divergent tips of epimeres I and constricted posteriorly stylophore. In Dissonus setae $d G I I$ are present, epimeres I are parallel and stylophore is rounded posteriorly.

- Etymology

This generic name is derived from the name "Galliformes" - the name of bird order hosting mites of this new genus.

\section{GALLIPHILOPSIS FRANCOLINUS SP. N.}

- Female (Figs 1-5)

Total body length of holotype 535 (500-550 in four paratypes).

Gnathosoma. Hypostomal apex as in Figure 3. Stylophore constricted posteriorly, 145 (145-150) long. Peritremes M-shaped, each transversal branch with one- 


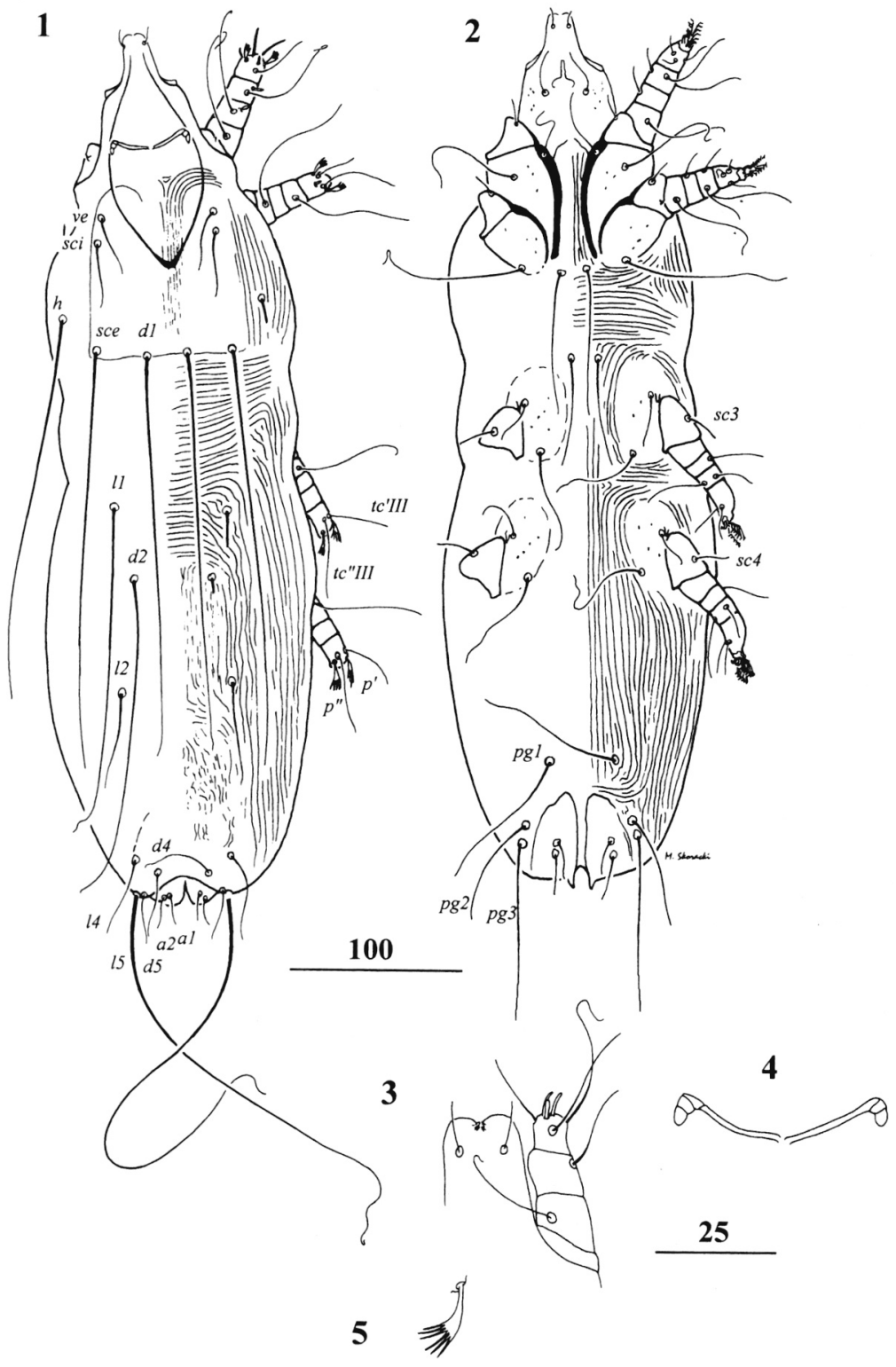

Figs 1-5. - Galliphilopsis francolinus sp. n. Female. 1. Dorsal view. 2. Ventral view. 3. Gnathosoma in ventral view. 4. Peritremes. 5. Fan seta p'III.

two chambers, each longitudinal branch with twothree chambers (Fig. 4).

Idiosoma. Propodosomal plate weakly sclerotized, deeply concave on anterior margin. Setae ve and $s c i$ subequal in length. Hysterosomal plate with indistinct margins. Hysterosomal setae $l 1$ and $d 2$ subequal in length and about four times longer than 12 . Pygidial setae $d 4$ and $d 5$ subequal in length. Cuticular striations as in Figures 1 \& 2.

Legs. Setae $t c$ "III-IV 1.2-1.3 times longer than $t c$ 'III-IV. Setae $p$ ' and $p$ " of legs III and IV with 7-8 tines (Fig. 5). Coxae I-IV well developed.

Lengths of setae: ve 30 (30-40), sci 35 (30-40), h 220 (205-235), sce (235-250); d1 (225-250); $l 1195$ (210-220); 1255 (45); 1445 (40); $l 5280$ (260); d2 195 (195-205); d4 30 (30-40); d5 30 (30); $a 1$ and $a 220$ (15-20); $g 1$ and g2 (20-30); pg1 90 (80-90); pg2 (65-70); pg3 (95-
105); sc2 20; sc3 (25); sc4 25 (25); tc'III-IV 35 (30-35); tC' III-IV 45 (45)

- Type material

Holotype female (No. Syr.11.1) and four female paratypes from the Orange River Francolin Francolinus levalliantoides (Smith, 1836) (Galliformes: Phasianidae) from South Africa, no other data. Holotype and paratypes are deposited at UAM except one female paratype at ZIN

- Etymology

The name francolinus refers to the generic name of the host.

- Differential diagnosis

The females of the new species are distinguished from other species of this genus: G. bochkovi sp. n. and 
G. lophurus sp. n. (cf. infra) by the presence of subequal hysterosomal setae $d 2$ which are about four times longer than 12. In the females of $G$. bochkovi and $G$. lophurus setae $d 2$ and 12 are short and subequal in the length.

\section{GALLIPHILOPSIS BOCHKOVI SP. N.}

- Female (Figs 6-9)

Total body length of holotype 495 (435-535 in four paratypes).

Gnathosoma. Stylophore constricted posteriorly, 155 (145-165) long. Peritremes M-shaped, each transversal branch with two chambers, each longitudinal branch with three chambers (Fig. 8).

Idiosoma. Propodosomal plate deeply concave on anterior margin and between setae $d 1$ and sce. Setae $v e$ and $s c i$ subequal in length. Hysterosomal plate with indistinct margins. Hysterosomal setae 12 and $d 2$ sube- qual in length and 4-5 times shorter than 11 . Pygidial setae $l 41,7$ times longer than $d 4$ and $d 5$. The length ratio of paragenital setae $p g 1, p g 2$ and $p g 3$ 1.2-1.3: 1:1.6. Cuticular striations as in Figures $6 \& 7$.

Legs. Setae $t c$ " $I I I-I V 1.5$ times longer than $t c ' I I I-I V$. Setae $p$ ' and $p$ " of legs III and IV with 7-8 tines (Fig. 9). Coxae I-IV well sclerotized.

Lengths of setae: ve 35 (30-35), sci 35 (40), h (215-245), sce (245-270); d1 265 (275-295); $l 1175$ (170-180); $l 245$ (40-45); 1460 (70-80); 15 (300-355); d2 40 (35-40); d4 40 (40-45); d5 30 (35); a1 15 (15-20); a2 20 (20); g1 25 (35); g2 35 (40); pg1 (9095); pg2 (70-75); pg3 (115-125); sc1 (15); sc2 (25); sc3 40 (30-40); sc4 25 (25-30); tc'IIIIV 25 (30); tc''III-IV 35 (45).

- Type material

Holotype female (No. Syr.12.1) and four female paratypes from Tragopan sp. (Galliformes: Phasianidae) from Himalaya, no other data. Holotype and most of
6

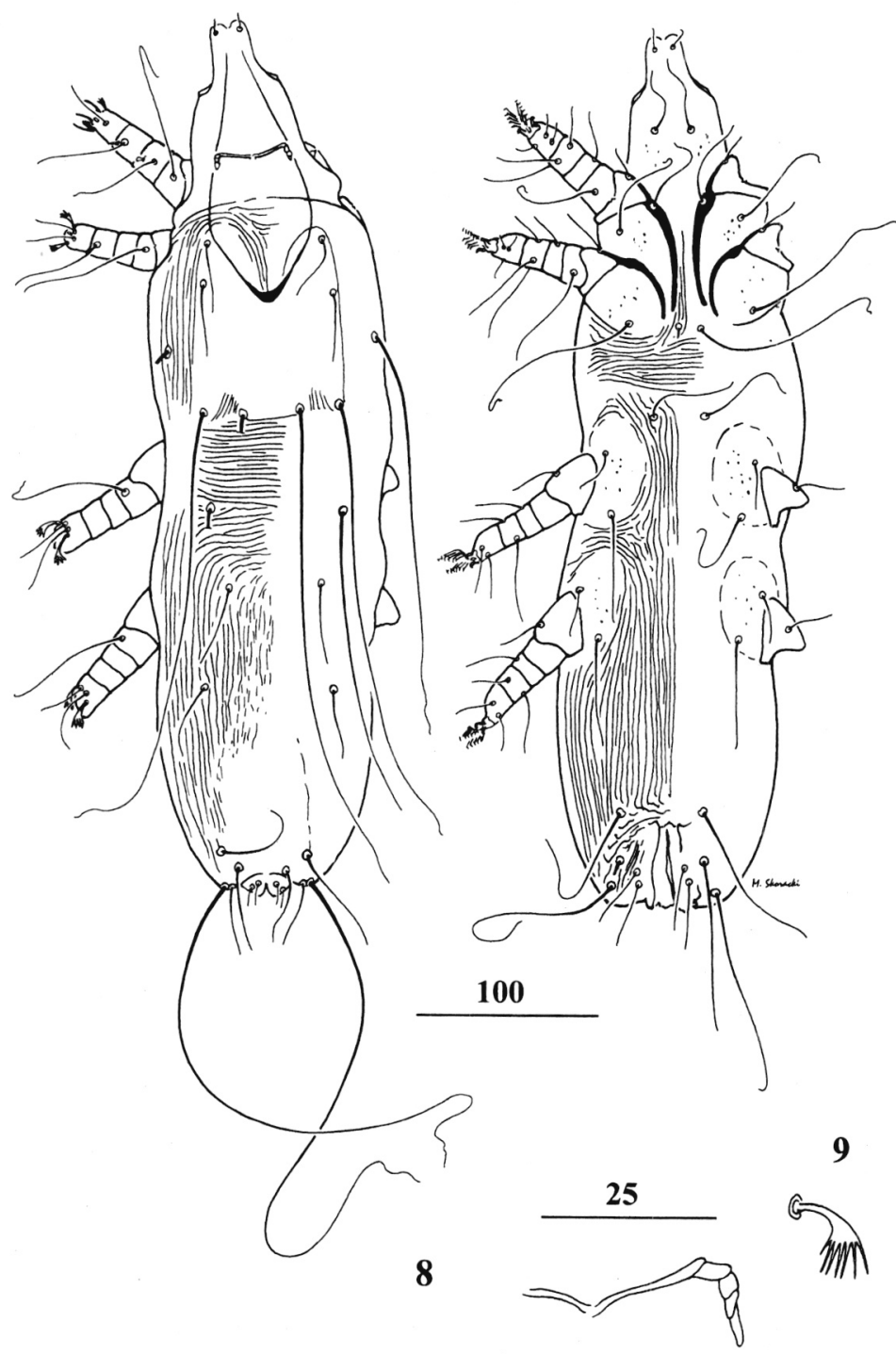

Figs 6-9. - Galliphilopsis bochkovi sp. n. Female. 6. Dorsal view. 7. Ventral view. 8. Peritremes. 9. Fan seta p'III. 
paratypes are deposited at UAM except two female paratypes at ZIN.

- Additional material

4 females (Nos. Syr.13.1-4) from the Barbary Partridge Alectoris barbara (Bonnaterre, 1791) (Galliformes: Phasianidae) from Sicily, Italy, no other data. Whole material is deposited at UAM.

- Etymology

This species is dedicated to Dr Andre V. Bochkov (Zoological Institute Russian Academy of Sciences, St. Petersburg) a well known acarologist as well as our friend.

- Differential diagnosis

The females of this new species are distinguished from the other species of this genus: G. francolinus sp. n. and $G$. lophurus sp. n. (cf. infra) by the presence of hysterosomal setae $l 1$ which are $4-5$ times longer than $d 2$ and 12 . In the females of $G$. francolinus sp. n. the setae $l 1$ and $d 2$ are subequal and about four times longer than 12 . In the females of $G$. lophurus sp. n. the setae $11, d 2$ and $l 2$ are short and subequal in the length.

\section{GALLIPHILOPSIS LOPHURUS SP. N.}

- Female (Figs 10-13)

Total body length of holotype 465 (455-465 in seven paratypes).

Gnathosoma. Stylophore constricted posteriorly, 140 (135-140) long. Peritremes M-shaped, each transversal branch with one-two chambers, each longitudinal branch with two-three chambers (Fig. 12).

Idiosoma. Propodosomal plate deeply concave on anterior margin. Setae ve and sci subequal in length. Hysterosomal plate fused with pygidial plate. Setae $d 2$, 14 and $d 4$ situated on hysterosomal plate. Hysterosomal
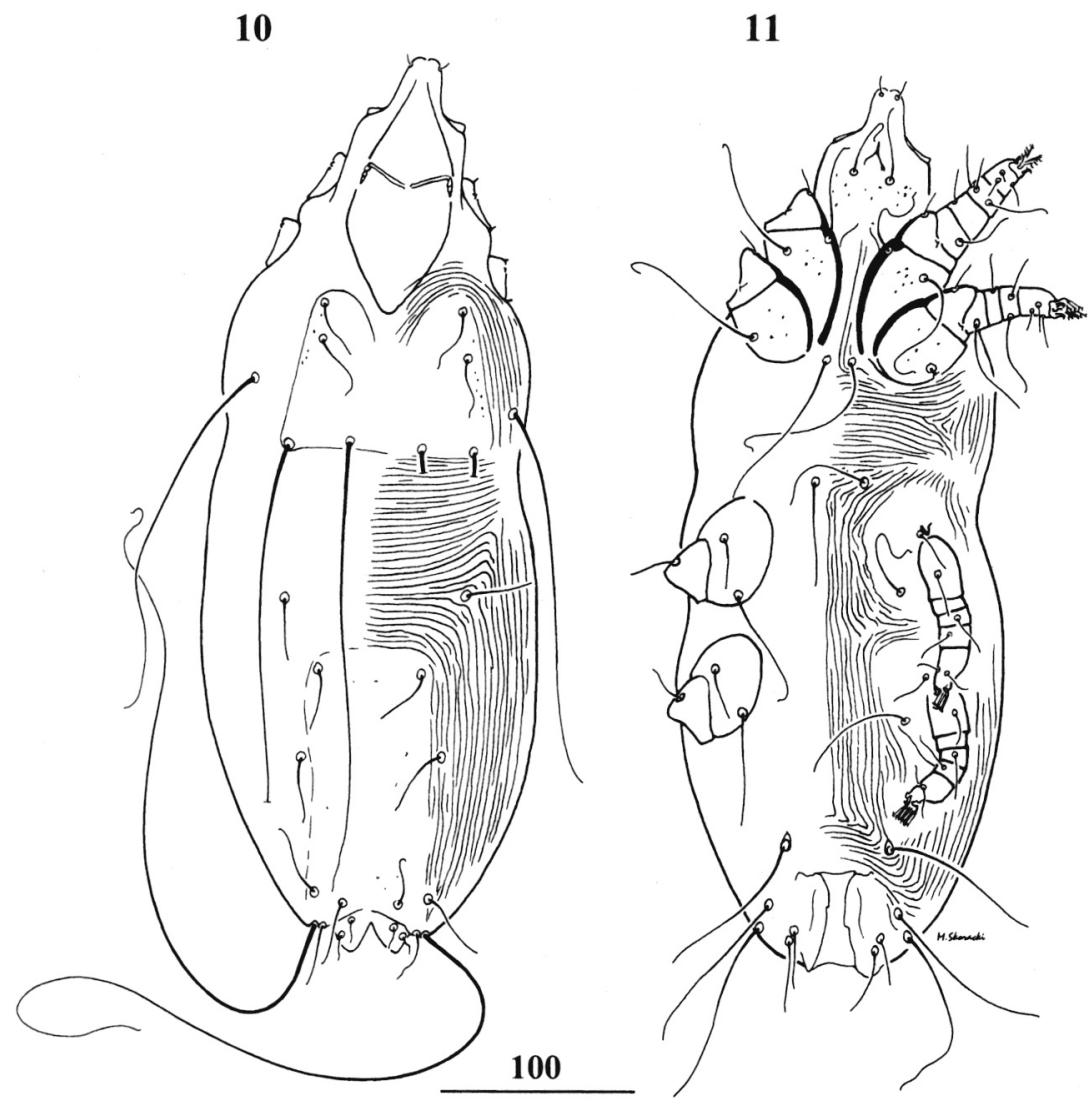

Figs 10-13. - Galliphilopsis lophurus sp. n. Female. 10. Dorsal view. 11. Ventral view. 12. Peritremes. 13. Fan seta $p ' I I I$.

12

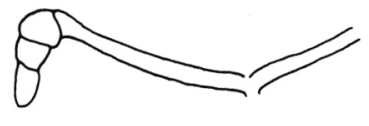

25

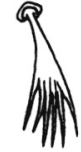


setae 11,12 and $d 2$ subequal in length. Pygidial setae $14, d 4$ and $d 5$ subequal in length. Setae 15 long, about 10 times longer than $14, d 4$ and $d 5$. Paragenital setae pg1, pg2 and pg3 subequal in length. Cuticular striations as in Figures 10 \& 11.

Legs. Setae $t c$ " III-IV 1.2 times longer than $t c ' I I I-I V$. Setae $p^{\prime}$ and $p$ ' of legs III and IV with 6-8 tines (Fig. 13). Coxae I-IV well sclerotized.

Lengths of setae: ve (30-35), sci (30-40), b (205-215), d1 (240); 1125 (20-25); 1225 (20-25); 1440 (35); 15 (330); d2 25 (20-25); $d 435$ (30); $d 525$ (25-35); $a 1$ and a2 15 (15); g1 30 (25-30); g2 35 (25-35); pg1 (80); pg2 (80); pg3 (80); sc1 15 (15); sc2 20 (15-20); sc3 25 (2025); sc4 (20); tc'III-IV 35 (35); tc'III-IV 45 (40-45); ic1 70 (75).
- Type material

Holotype female (No. Syr.18.1) and seven female paratypes from the Kalij Pheasant Lophura leucomelanos (Latham, 1790) (Galliformes: Phasianidae), no other data. Holotype and most of paratypes are deposited at UAM except two female paratypes at ZIN and one female paratype at SNM.

- Etymology

The name lopburus refers to the generic name of the host.

- Differential diagnosis

The females of this new species are distinguished from the other species of this genus: G. francolinus sp. n. and $G$. bochkovi sp. n. (cf. supra) by the pre-

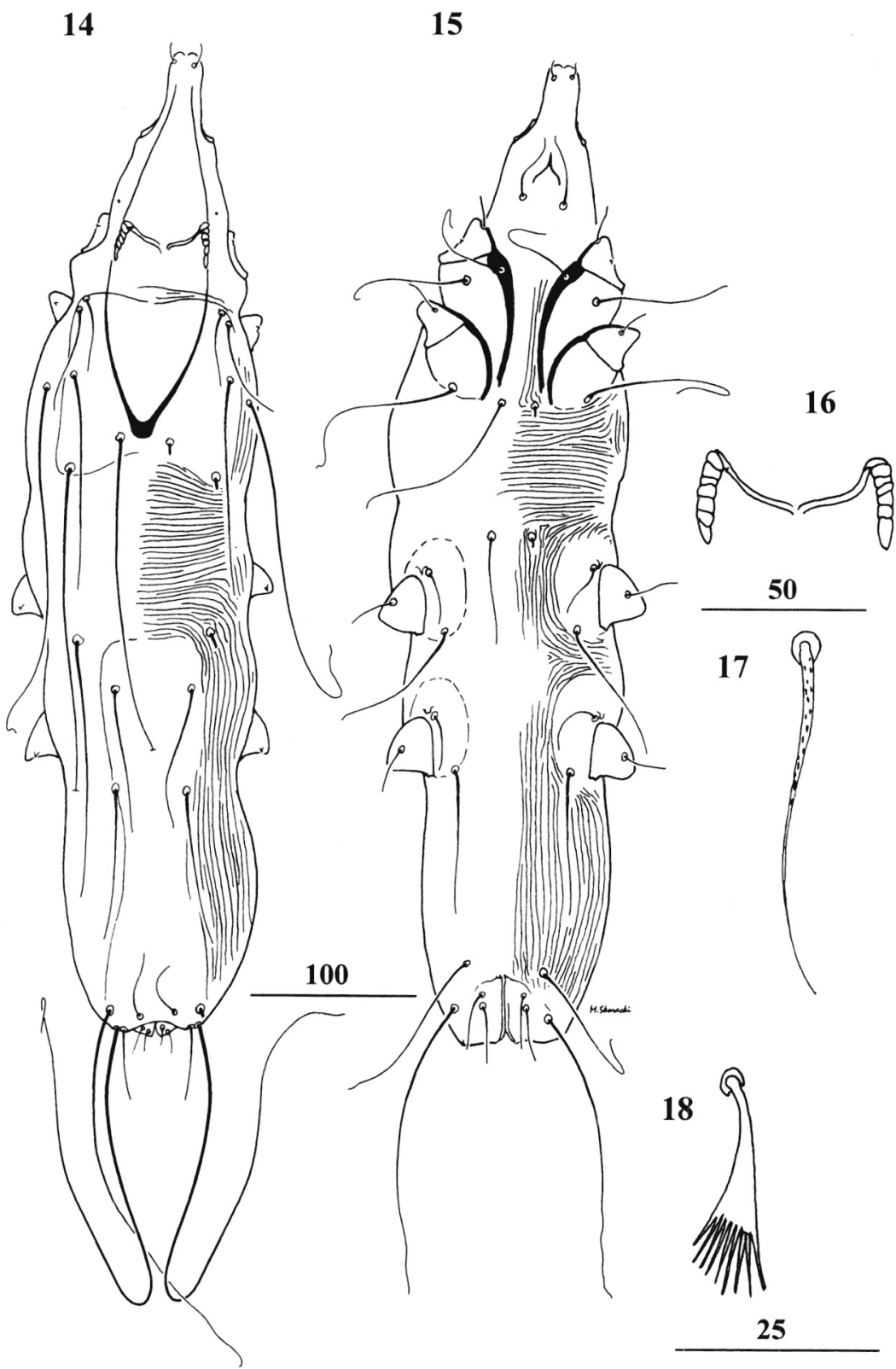

Figs 14-18. - Mironovia rouloul sp. n. Female. Female. 14. Dorsal view. 15. Ventral view. 16. Peritremes. 17. Seta vi. 18. Fan seta p'III. 
sence of subequal hysterosomal setae $l 1, d 2$ and $l 2$. In the females of $G$. francolinus sp. n. the setae $l 1$ and $d 2$ are subequal and about four times longer than 12 . In the females of $G$. bochkovi sp. n. the setae 11 are 4-5 times longer than $d 2$ and $l 2$.

\section{MIRONOVIA ROULOUL SP. N.}

\section{- Female (Figs 14-18)}

Total body length of holotype 590 (600 in one paratype).

Gnathosoma. Stylophore constricted posteriorly, 230 (235) long. Peritremes M-shaped, each transversal branch with two chambers, each longitudinal branch with six-seven chambers (Fig. 16).

Idiosoma. Propodosomal plate well sclerotized, bearing setae $v i$, ve, sci, sce and $d 1$. Propodosomal setae with fine knobbs (Fig. 17), other idiosomal setae smooth. Length ratio of setae $v i$, ve and sci 1:1.4-1.6:3. Hysterosomal plate fused with pygidial plate. Setae $d 2,12$, 14 and $d 4$ set on hysterosomal plate. Hysterosomal setae $l 11.4$ times longer than $l 2$ and $d 2$. Paragenital setae pg2 1.7-1.8 times longer than pg1. Cuticular striations as in Figures $14 \& 15$.

Legs. Epimeres I slightly divergent and not fused to epimeres II. Setae tc" III-IV 1.6-1.7 times longer than tc'III-IV. Setae $p$ ' and $p$ " of legs III and IV with 8-10 tines (Fig. 18). Coxae I-IV weakly sclerotized.

Lengths of setae: vi 40 (40); ve 65 (55), sci 135 (120), b 215 (190), sce >195; $l 1155$ (125); $l 290$ (90); l4 255; 15 395; d2 85 (90); d4 40 (35); d5 40 (35); $a 1$ and $a 215$ (20); g1 30 (25); g2 35 (25); pg1 105 (90); pg2 185 (150); sc1 (25); sc2 (25); sc3 35 (35); sc4 30 (25); tc'IIIIV 35 (40); tc'"III-IV 65 (70).

Male unknown.

- Type material

Holotype female (No. Syr.17.1) and one female paratype from the Crested Partridge Rollulus rouloul (Scopoli, 1786) (Galliformes: Phasianidae) from Sumatra, no other data. Whole material is deposited at UAM.

\section{- Etymology}

The name rouloul refers to the specific name of the host.

\section{- Differential diagnosis}

The females of this new species differs from the typespecies of this genus, M. phasiani Chirov and Kravtsova, 1995 described from Phasianus colchicus (Phasianidae) by the combination of the following features: the length ratio of setae vi:ve:sci is $1: 1.4-$ 1.6:3; the setae $l 1$ are longer than $l 2$ and $d 2$. In females of $M$. phasiani the length ratio of setae vi:ve:sci is $1: 1.3: 1.4$; the setae $l 1$ are shorter than $d 2$ and 12 .

\section{SYRINGOPHILUS BIPECTINATUS HELLER, 1880}

Syringophilus bipectinatus is widely distributed in the world together with its host, the domestic chicken Gallus gallus domesticus (cf. Bochkov \& Mironov, 1998). This species was also reported from Ptilopachus petrosus from Cameroun (Skoracki \& Sikora, 2003). Below, we give additional new host species for $S$. bipectinatus.

- Material examined

15 females, three males, four nymphs, one larva from the Red-legged Partridge Alectoris rufa (L., 1758) (Galliformes: Phasianidae) from Corsica, no other data. Most part of this material is deposited at UAM except two females, one male at ZIN and two females at SNM.

\section{ACKNOWLEDGEMENTS}

W e would like to express our appreciation to Prof. Tadeusz Stawarczyk and Dr. Jan Lontkowski (Natural Museum of the Wroclaw University, Poland) for loaning the bird materials for the present study. We are also grateful to Dr. Jacek Dabert (Department of Animal Morphology, A. Mickiewicz University, Poland) and Dr. Andre V Bochkov (Zoological Institute, St. Petersburg, Russia) for their critical reading of the manuscript. Many thanks to Ewelina and Winfried Just (Ohio University, USA) for correcting the English. The present research was supported by the Foundation for Polish Science (2003).

\section{REFERENCES}

BochKov A.V. Syringophilus numidae sp. n. a new species of quill mites (Acarina: Syringophilidae) ex Numida meleagris (Galliformes: Phasianidae) from South Africa. Acarina, 2000, 8, 103-104.

Bochkov A.V. \& Mironov S.V. Quill mites of the family Syringophilidae Lavoipierre, 1953 (Acariformes: Prostigmata) parasitic on birds (Aves) of the fauna of the former USSR. Acarina, 1998, 6, 3-16.

CASTO S.D. Cuculiphilus lobatus gen. n., sp. n. representing a new subfamily of quill mites (Acarina: Syringophilidae) from the groove-billed ani, Crotophaga sulcirostris (Cuculiformes: Cuculidae). Southwestern Naturalist, 1977, 22, 169-176.

Casto S.D. A new genus of the syringophilid mites from galliform birds in Texas. Texas Journal of Science, 1980, 32, 233-240.

Chirov P.A. \& Kravtsova N.T. A new genus and new species of mites of the family Syringophilidae. Parazitologiya, 1995, 29, 370-379. (In Russian).

Fain A. Idiosomal and leg chaetotaxy in the Cheyletidae. International Journal of Acarology, 1979, 5, 305-310. 
Fain A., Bochkov A.V. \& Mironov S.V. New genera and species of quill mites of the family Syringophilidae (Acari: Prostigmata). Bulletin de l'Institut Royal des Sciences Naturelles de Belgique (Entomology), 2000, 70, 33-70.

GrandjEAn F. Observations sur les acarines de la famille des Stigmaeidae. Archives des Sciences physiques et Naturelles, 1944, 26, 103-131.

HOward R. \& MOORE A.A. A complete checklist of the birds of the World. Second Ed. 622 p. Academic Press, London, 1991.

Kethley J.B. A revision of the family Syringophilidae (Prostigmata: Acarina). Contributions of the American Entomological Institute, 1970, 5, 1-76.

KetHley J.B. A new genus and species of quill mites (Acarina: Syringophilidae) from Colinus virginianus (Galliformes: Phasianidae) with notes on developmental chaetotaxy. Fieldiana Zoology, 1973, 65, 1-8.

Philips J.R. \& NorTon R.A. Bubophilus ascalaphus gen. and sp. n. (Acarina: Syringophilidae) from the quills of a great horned owl (Bubo virginianus). Journal of Parasitology, 1978, 64, 900-904.

Skoracki M. New genus and species of Syringophilidae (Acari: Prostigmata) from Eurasian Reed Warbler, Acrocephalus scirpaceus (Sylviidae: Passeriformes). Genus, 10, 155-162.

SKORACKI M. \& DABERT J. Syringophilopsis albicollisi sp. n., a new species of the quill mite of the family Syringophilidae (Acari: Prostigmata). Acarina, 2000, 8, 59-63.

Skoracki M., Magowski W. \& Dabert J. Picobia polonica sp. n. (Acari: Prostigmata: Syringophilidae), a new species of quill mite from the domestic hen, Gallus gallus domesticus (Aves: Phasianidae). Folia Parasitologica, 2001, 48, 154158.

SKORACKI M. \& SiKORA B. Quill mites (Acari: Prostigmata: Syringophilidae) from African passeriform birds. Zootaxa, 129, $1-10$.

Zoonomen Nomenclatural data 2002 Alan P. Peterson: http:// www.zoonomen.net

Reçu le 13 novembre 2003 Accepté le $1^{\text {er }}$ septembre 2004 